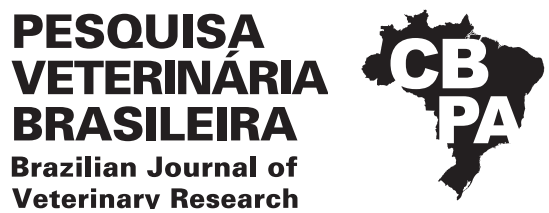

Pesq. Vet. Bras. 41:e06669, 2021

DOI: 10.1590/1678-5150-PVB-6669

Original Article

Veterinarv Research

ISSN 0100-736X (Print)

Livestock Diseases

ISSN 1678-5150 (Online)

\title{
Agents of pneumonia in slaughtered pigs in southern Brazil $^{1}$
}

\author{
Elisa R. De Conti², Karine L. Takeuti² ${ }^{2}$ Claiton I. Schwertz ${ }^{3}$, Ronaldo M. Bianchi ${ }^{3}$, \\ David Driemeier ${ }^{3}$ and David E.S.N. de Barcellos ${ }^{2 *}$ (iD
}

\begin{abstract}
De Conti E.R., Takeuti K.L., Schwertz C.I., Bianchi R.M., Driemeier D., de Barcellos D.E.S.N. 2021. Agents of pneumonia in slaughtered pigs in southern Brazil. Pesquisa Veterinária Brasileira 41:e06669, 2021. Universidade Federal do Rio Grande do Sul, Av. Bento Gonçalves 9090, Bairro Agronomia, Porto Alegre, RS 91540-000, Brazil. E-mail: davidbarcellos@terra.com.br

A high prevalence of pneumonic lesions has been reported to affect slaughtered pigs in southern Brazil. In order to identify which microorganisms have been causing those lesions, 30 pig lungs presenting pneumonic gross lesions were collected from five different slaughterhouses, totaling 150 lungs. Samples for bacterial isolation, molecular, histopathologic and immunohistochemistry (IHC) evaluation were taken from each lung. The pneumonic lesion scoring ranged from 1.53 to 2.83. The most frequent histopathological lesions found was the concomitant Influenza A virus (IAV) and Mycoplasma hyopneumoniae infection, corresponding to 55.3\% (83/150), and Pasteurella multocida type A was isolated in 54.2\% $(45 / 83)$ of these cases. In 102 samples (68\%), there was histopathologic suggestion of involvement of more than one infectious agent. M. hyopneumoniae was the most frequent agent associated with pneumonic lesions, being present in 92.1\% (94/102) of the lungs with coinfections, followed by IAV in $89.2 \%(91 / 102)$. Besides the coinfections, IAV lesions were observed also in six samples without another pathogenic microorganism detected. A total of 46 samples with acute and subacute IAV suspected lesions in histopathological examination were assessed for IHC and real time RT-PCR for IAV. A total of 35\% (16/46) of them were positive by IHC and 13\% (6/46) by real time RT-PCR. Regarding M. hyopneumoniae, 79.3\% $(119 / 150)$ of samples were positive by qPCR and $84.9 \%$ (101/119) of them also presented $M$. hyopneumoniae suspected lesions in the histopathological examination. The results of this study suggest the importance of IAV in respiratory diseases in finishing pigs, even though this virus is more frequently reported in the nursery phase. In addition, our results emphasize the importance of lung coinfections in finishing pigs.
\end{abstract}

INDEX TERMS: Pneumonia, slaughter, pigs, Brazil, influenza A, Mycoplasma hyopneumoniae, Pasteurella multocida, coinfections, lungs, pneumonic lesions.

RESUMO.- [Agentes patogênicos de pneumonia em suínos abatidos no sul do Brasil.] Lesões sugestivas de pneumonia são frequentemente encontradas em altas prevalências em suínos abatidos no sul do Brasil. Para identificar quais microrganismos causam essas lesões, foram coletados 30

\footnotetext{
${ }^{1}$ Received on April 8, 2020.

Accepted for publication on August 17, 2020.

${ }^{2}$ Setor de Suínos, Departamento de Medicina Animal, Faculdade de Veterinária, Universidade Federal do Rio Grande do Sul (UFRGS), Av. Bento Gonçalves 9090, Porto Alegre, RS 91540-000, Brazil. *Corresponding author: davidbarcellos@terra.com.br

${ }^{3}$ Setor de Patologia Veterinária, Departamento de Medicina Animal, Universidade Federal do Rio Grande do Sul (UFRGS), Av. Bento Gonçalves 9090, Porto Alegre, RS 91540-000, Brazil.
}

pulmões de suínos com lesão macroscópica sugestiva de pneumonia em cinco frigoríficos diferentes, totalizando 150 pulmões. Amostras para isolamento bacteriano, avaliação molecular, histopatológica e imuno-histoquímica (IHC) foram coletadas de cada pulmão. 0 escore de lesão pulmonar variou entre 1,53 a 2,83. 0 achado histopatológico mais observado foi a lesão sugestiva de infecção concomitante pelo vírus Influenza A (IAV) e Mycoplasma (M.) hyopneumoniae, correspondendo a 55,3\% (83/150), e em 54,2\% (45/83) desses casos Pasteurella (P.) multocida tipo A foi isolado. Em 102 amostras (68\%), houve lesão histopatológica sugestiva do envolvimento de mais de um agente infeccioso. M. hyopneumoniae foi o microrganismo mais frequente associado a lesões de pneumonia, estando 
presente em 92,1\% (94/102) dos pulmões com coinfecções, seguido de IAV, que foi encontrado em 89,2\% (91/102). Além das coinfecções, lesões de IAV foram observadas em mais seis amostras que não aparentavam envolvimento de outro agente infeccioso. Um total de 46 amostras com suspeita de lesão aguda e subaguda de IAV no exame histopatológico foram avaliadas para IHC e RT-PCR em tempo real para IAV e 35\% (16/46) delas foram positivas por IHC e 13\% (6/46) foram positivas por RT-PCR em tempo real. Com relação a M. hyopneumoniae, $79,3 \%(119 / 150)$ das amostras foram positivas por qPCR e $84,9 \%(101 / 119)$ delas também apresentaram lesões suspeitas de M. hyopneumoniae no exame histopatológico. Os resultados deste trabalho sugerem a importância do IAV como agente causador de pneumonias em suínos de terminação, embora esse vírus seja mais frequentemente relatado na fase de creche. Além disso, os achados deste trabalho demonstram a presença frequente de coinfecções pulmonares em suínos de terminação.

TERMOS DE INDEXAÇ̃̃̃: Pneumonia, suínos, Brasil, influenza A, Mycoplasma hyopneumoniae, Pasteurella multocida, coinfecções, pulmões, lesões de pneumonia.

\section{INTRODUCTION}

Respiratory diseases correspond to a multifactorial problem in pigs and it is one of the major concerns to swine production. The economic losses are caused by increased pig mortality and intense use of antibiotics and vaccines and reduced daily feed gain and poor feed conversion rates (Haden et al. 2012). Pneumonic lesions are the most common finding in pig lungs at slaughter in many countries (Fraile et al. 2010, Fablet et al. 2012, Brewster et al. 2017, Karabasil et al. 2017). The relationship between pneumonic lesions and losses of pig carcasses quality is also known, measured as a reduction of the post-trimming carcass weight in 1.26kg (Brewster et al. 2017).

The Porcine Respiratory Disease Complex (PRDC) is characterized by the coinfection of two or more bacterial or viral agents that act in synergism exacerbating the clinical signs especially in growing and finishing pigs. The occurrence of pneumonia at the end of the finishing phase in Brazilian pig herds is frequent. Studies of the last two decades showed a prevalence of pneumonic lesions in pigs at slaughter up to $75.7 \%$ (Silva et al. 2002). In a recent study evaluating the etiology of swine pneumonia in the finishing phase in Brazil, the bacterial agents found were Mycoplasma hyopneumoniae, Pasteurella multocida, M. hyorhinis, Actinobacillus pleuropneumoniae, Glaesserella parasuis (formerly Haemophilus parasuis), Streptococcus suis, and Trueperella pyogenes by PCR, bacterial isolation and immunohistochemistry (IHC) testing. The viral agents identified were Influenza A (IAV) and Porcine Circovirus type 2 (PCV2) by IHC. In total, $58.8 \%$ of the pigs submitted to the study were infected with more than one agent (Morés et al. 2015). Regarding the coinfection nature of PRDC in finishing pigs, the proper diagnostic of the microorganisms involved in pneumonic lesions is crucial to the determination of control measures at the farm level. Taking this into account, the aim of this work was to evaluate the etiological agents involved in pig pneumonia at different slaughterhouses in southern Brazil.

\section{MATERIALS AND METHODS}

Ethics statement. The study was approved by the Institutional Animal Care and Use Committee of the "Universidade Federal do Rio Grande do Sul”, Brazil.

Study design and sampling. Five slaughterhouses under Federal Inspection Service (SIF), which slaughter pigs from five different companies (A, B, C, D, and E) located in the state of Rio Grande do Sul, Brazil, were selected for the study. Thirty lungs with macroscopic pneumonic lesions were randomly selected from two different batches in each slaughterhouse, totaling 150 lungs. The average age of the slaughtered animals was approximate 180 days. The lungs were collected for further score evaluation and sampling. Two fragments from transitional areas of each lung were sampled. One $4 \mathrm{~cm} \times 4 \mathrm{~cm}$ fragment was collected and stored under refrigeration for bacteriological isolation and quantitative polymerase chain reaction (qPCR). A second fragment measured approximately $2 \mathrm{~cm}^{3}$ was collected and fixed in a $10 \%$ neutral buffered formalin for histopathological and immunohistochemical examination.

Lung lesion scoring. The severity index of pneumonic lesions was performed according to the methodology described by Madec \& Kobisch (1982). Briefly, each pulmonary lobe contributes independently to the scoring, according to its proportion concerning the total lung area. The pulmonary lobes received a score from 0 to 4 according to the extent of the pulmonary consolidation lesion, where: $0=$ normal lobe, without consolidation, $1=$ from 1 to $25 \%$ of the lobe with consolidation, 2 = from $26 \%$ to $50 \%, 3=$ from $51 \%$ to $75 \%$, and $4=$ from $76 \%$ to $100 \%$ of the affected lobe area with consolidation injury.

Bacterial isolation. Each sample was plated in sheep Blood Agar 5\% (Kasvi ${ }^{\circledR}$, Italy) and MacConkey Agar (Becton, Dickinson and Company ${ }^{\circledR}$, USA) and incubated at $37^{\circ} \mathrm{C}$ for 24 to 48 hours in aerobic conditions. Biochemical tests were performed to identify the colonies, as described by Markey et al. (2013). In the presence of pleuritis, necro-hemorrhagic areas of consolidation or nodules of necrosis in the lungs, microaerophilic incubation would be performed.

Histopathological exam. After $24 \mathrm{~h}$ of formalin fixation, each lung was routinely processed and embedded in paraffin blocks. Histological sections of 3-5 $\mu \mathrm{m}$ were stained by hematoxylin-eosin (HE), as described by Allen (1992), for further description of the histopathologic lesions. All samples that were suspected of Influenza A virus were classified in an acute (suppurative necrotizing bronchiolitis/ bronchitis), subacute (proliferative bronchiolitis/bronchitis associated with bronchointerstitial pneumonia), or chronic (bronchiolitis obliterans and fibrous tissue) lesion (Watanabe et al. 2012). Lung samples with BALT (bronchus-associated lymphoid tissue) hyperplasia were considered indicative of Mycoplasma hyopneumoniae infection (Blanchard et al. 1992). Suppurative bronchopneumonia with fibrin deposition was considered indicative of bacterial involvement in the etiology of the lesion, especially Pasteurella multocida.

Immunohistochemistry for Influenza A. Samples with acute and subacute lesions suggestive of Influenza virus infection in the histopathological evaluation were submitted to immunohistochemistry (IHC) for IAV. Briefly, the sample sections were placed on glass slides coated with poly-L-lysine and heated at $57^{\circ} \mathrm{C}$ until dry. The biotinstreptovidine-peroxidase Kit (Kit Lsab + System-HRP, Dako ${ }^{\circledR}$, USA) was used to detect the presence of IAV. The endogenous activity of peroxidase was inhibited by immersion in the slides in methanol solution at $10 \%$ hydrogen peroxide for 10 minutes. Antigenic recovery was performed with enzymatic treatment using $0.05 \%$ protease XIV (Sigma ${ }^{\circledR}$, USA) for 25 minutes at $37^{\circ} \mathrm{C}$. All slides were incubated with primary antibodies Anti-IA (Millipore, dilution 1:800) overnight at $4^{\circ} \mathrm{C}$. The chromogen used was the 3.3-Diaminobenzidine (Dako ${ }^{\circledR}$, USA) with Harris' Hematoxylin 
as counterstain (Watanabe et al. 2012). The IAV positivity immune staining was assessed according to the structure, being classified as marked in the epithelium, bronchi and bronchioles, and macrophages.

Real-time PCR for Influenza A. Samples with acute and subacute lesions suggestive of Influenza infection in the histopathological evaluation were also submitted to real-time RT-PCR for IAV. Due to the short time for detection of the virus in lung tissue (Schaefer et al. 2013), samples with characteristic chronic lesions were not submitted to this test. The extraction of RNA was performed with a commercial extraction kit based on a silica column (AllPrep DNA/RNA Mini Kit, Qiagen ${ }^{\circledR}$, Germany) as recommended by the manufacturer. The PCR reaction for IAV was performed from the extracted RNA, as described by the CDC (Centers for Disease Control, Atlanta, United States of America; World Health Organization) (WHO 2010). Samples were evaluated in duplicate, and two positive and two negative controls were added to each analysis.

Real-time PCR for Mycoplasma hyopneumoniae. The DNA extraction was performed with a commercial extraction kit based on a silica column (Purelink Genomic DNA Mini kit, Thermo Fisher Scientific $^{\circledR}$, USA) following manufacturer's instructions. The PCR was performed in all samples, according to Takeuti et al. (2017). The samples were evaluated in duplicate, and two additional positive and negative were added to each analysis.

Statistical analysis. Multiple pairwise comparison tests of proportion with Bonferroni correction were performed in R v3.2 (R Core Team 2013) to compare the prevalence of positive lungs for P. multocida by isolation and the prevalence of positive samples for IAV and M. hyopneumoniae by PCR among the companies. Quisquare analysis was performed to compare absence or presence of histopathological lesions, bacterial isolation and PCR results. Statistical significance was considered when $P$-values were less than 0.05 .

\section{RESULTS}

Pulmonary scoring at slaughter. All selected lungs presented macroscopic pneumonic lesions. The only pattern of lesion observed was cranioventral consolidation (Fig.1A).
The mean lung lesion score ranged from 1.53 to 2.83 among companies (Table 1$)$. No lungs (0/150) had pleuritis, necrohemorrhagic areas of consolidation or nodules of necrosis.

Bacteriology. Pasteurella multocida type A was the only bacterium isolated with relevance to pneumonic lesions. The bacterium was isolated in 43.3\% (65/150) of the lungs, and company $\mathrm{C}$ did not have any lung sample with $P$. multocida type A isolation. However, companies D and E presented a higher number of lungs with $P$. multocida type A isolation when compared to companies A and C (Table 1).

Histopathological evaluation. There was a predominance of lung lesions suggestive of Mycoplasma hyopneumoniae and Influenza A virus (IAV) coinfection, representing 55.3\% (83/150) of the lungs, followed by $28 \%$ (42/150) of samples suggestive of single $M$. hyopneumoniae infection (Fig.1B), and $9.3 \%(14 / 150)$ of samples indicative of single IAV infection

Table 1. Lung lesion scoring and distribution of positive lungs for Pasteurella multocida type A isolation, and Mycoplasma hyopneumoniae and Influenza A virus suggestive lesions by histopathological evaluation in five companies assessed in the study

\begin{tabular}{lccccc}
\hline \multicolumn{1}{c}{ Company } & $\mathrm{A}$ & $\mathrm{B}$ & $\mathrm{C}$ & $\mathrm{D}$ & $\mathrm{E}$ \\
\hline IAV & $86.7 \%^{\mathrm{a}}$ & $70.0 \%^{\mathrm{a}}$ & $20.0 \%^{\mathrm{b}}$ & $76.7 \%^{\mathrm{a}}$ & $70.0 \%^{\mathrm{a}}$ \\
& $(26 / 30)$ & $(21 / 30)$ & $(6 / 30)$ & $(23 / 30)$ & $(21 / 30)$ \\
Mhyo & $80.0 \%^{\mathrm{ab}}$ & $86.6 \%^{\mathrm{ab}}$ & $73.3 \%^{\mathrm{a}}$ & $90.0 \%^{\mathrm{b}}$ & $86.6 \%^{\mathrm{ab}}$ \\
& $(24 / 30)$ & $(26 / 30)$ & $(22 / 30)$ & $(27 / 30)$ & $(26 / 30)$ \\
PmA & $33.3 \%^{\mathrm{a}}$ & $50.0 \%^{\mathrm{ab}}$ & $0 \%^{\mathrm{c}}$ & $66.7 \% \%^{\mathrm{bd}}$ & $66.7 \%^{\mathrm{bd}}$ \\
& $(10 / 30)$ & $(15 / 30)$ & $(0 / 30)$ & $(20 / 30)$ & $(20 / 30)$ \\
LLS & 2.03 & 2.40 & 1.53 & 2.83 & 2.23
\end{tabular}

$\overline{\mathrm{IAV}}=$ Influenza A virus, Mhyo = Mycoplasma hyopneumoniae, $\mathrm{PmA}=$ Pasteurella multocida type A, LLS = lung lesion score; Different superscript letters within a row indicate statistically significant difference $(P<0.05)$ among the five companies (A, B, C, D, and E) based on multiple pairwise comparison tests of proportion analysis.
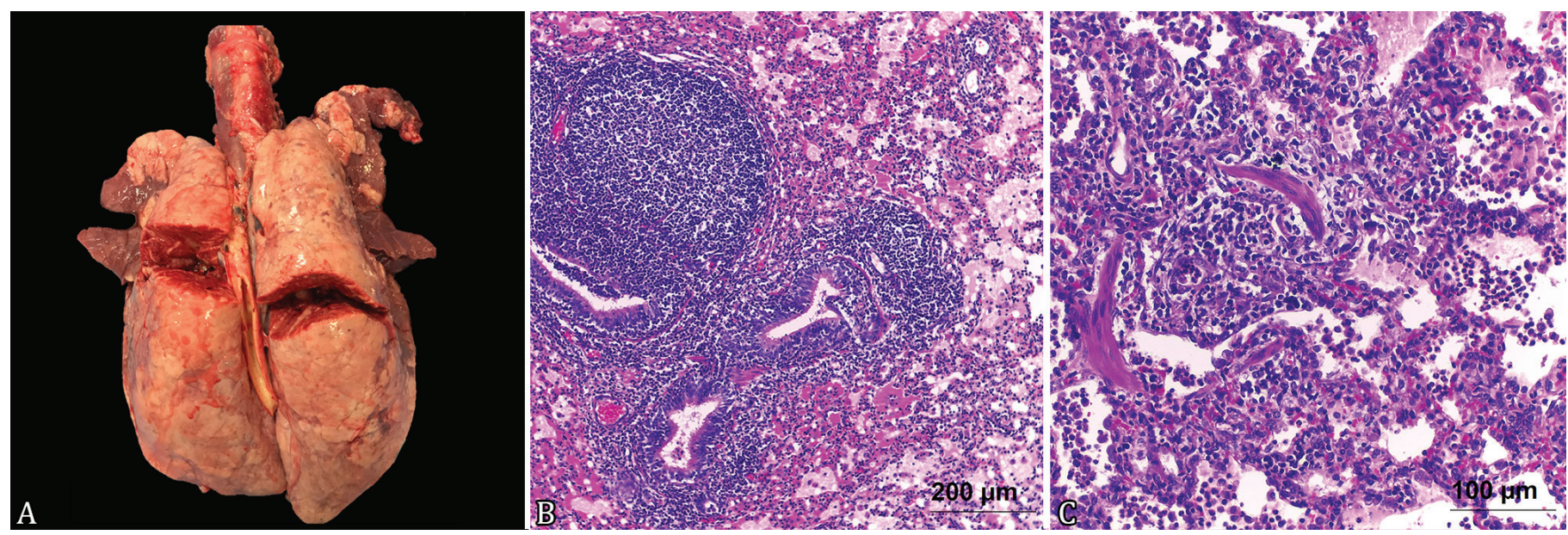

Fig.1. (A) Lung of a pig selected for the study, dorsal view. Multifocal to coalescent, reddish and firm areas in the cranial and middle lobes are observed (consolidation). The cuts in the diaphragmatic lobe were performed by the slaughterhouse inspection. (B) Histological aspect of the lung of a pig selected for the study. There is bronchointerstitial pneumonia associated with BALT (bronchus-associated lymphoid tissue) hyperplasia, edema and mild inflammatory infiltrate of macrophages in alveolar spaces. These lesions were observed in cases of Mycoplasma hyopneumoniae pneumonia. HE, obj.20x. (C) Histological aspect of the lung of a pig selected for the study. An area of bronchiolitis obliterans is observed associated with moderate inflammatory infiltrate of neutrophils and macrophages in alveolar and bronchiolar lumen. There is also type II pneumocytes hyperplasia, and interstitial inflammatory infiltrate of lymphocytes and plasma cells. These lesions were considered compatible with chronic Influenza A pneumonia. HE, obj.40x. 
(Fig.1C). Moreover, 7.4\% (11/150) of lung samples did not show any suspected lesion in the histopathological examination. Taking all histopathological results into account, a total of $64.7 \%(97 / 150)$ of them resulted in microscopic lesions suggestive of IAV infection, isolated or in a coinfection with $M$. hyopneumoniae. The association of histological lesions and P. multocida type A isolation is summarized in Table 2.

Immunohistochemistry and real-time RT-PCR for Influenza A. A total of 46 samples with acute and subacute IAV suspected lesions in histopathological examination were selected for IHC and real time RT-PCR for IAV. A proportion of $35 \%(16 / 46)$ of them were positive by IHC with macrophage marking, and $13 \%$ of the samples $(6 / 46)$ were positive by real time RT-PCR.

Detection of $M$. hyopneumoniae by real-time PCR (qPCR). A total of 79.3\% (119/150) of samples were positive for $M$. hyopneumoniae by qPCR. Companies A, B, D and E had similar results, ranging from $90 \%$ (A) to $100 \%$ (D) of positives samples, and the majority of samples also presented histopathological lesions suggestive of $M$. hyopneumoniae infection. On the other hand, company C presented only $16.6 \%$ (5/30) of positives samples by qPCR (Table 3 ).

\section{DISCUSSION}

All selected lungs of this study showed gross pneumonic lesions, as expected since it was a selection criterion in each slaughterhouse. The lungs of all companies showed high lesion scores, but company $\mathrm{C}$ presented the lowest scoring, which was in agreement with the laboratory results, since it was not possible to isolate Pasteurella multocida type A from any of the lungs. The presence of secondary bacteria in the lungs may result in more severe lesions (Loving et al. 2010), impacting in the performance of the pigs, leading to major economic losses (Pointon et al. 1985, Straw et al. 1990).

The only bacterium of importance in pig pneumonia isolated in this study was $P$. multocida type A. The isolation of this bacterium was expected since it is reported to be more prevalent than other $P$. multocida serotypes in lung coinfections. In a recent study, $90.9 \%$ of the $P$. multocida isolated in pigs lungs were type A and only 9.1\% type D (Paladino et al. 2017). Morés et al. (2015) have detected 100\% of P. multocida type

Table 2. Relationship between Pasteurella multocida type A isolation and histopathological lesions suggestive of IAV and Mycoplasma hyopneumoniae coinfections

\begin{tabular}{|c|c|c|c|}
\hline & \multicolumn{2}{|c|}{ Pasteurella multocida type A isolation } & \multirow{2}{*}{ Total } \\
\hline & Yes & No & \\
\hline IAV and Mhyo & $30.0 \%(45 / 150)$ & $25.3 \%(38 / 150)$ & $\begin{array}{c}55.3 \% \\
(83 / 150)\end{array}$ \\
\hline Mhyo & $7.3 \% \%^{\mathrm{a}}(11 / 150)$ & $20.7 \%^{\mathrm{b}}(31 / 150)$ & $\begin{array}{c}28 \% \\
(42 / 150)\end{array}$ \\
\hline IAV & $5.3 \%(8 / 150)$ & $4.0 \%(6 / 150)$ & $\begin{array}{c}9.3 \% \\
(14 / 150)\end{array}$ \\
\hline No lesions & $0.7 \% \%^{a}(1 / 150)$ & $6.7 \%^{\mathrm{b}}(10 / 150)$ & $\begin{array}{c}7.3 \% \\
(11 / 150)\end{array}$ \\
\hline Total & $43.3 \% \%^{\mathrm{a}}(65 / 150)$ & $56.7 \%^{\mathrm{b}}(85 / 150)$ & $\begin{array}{c}100 \% \\
(150 / 150)\end{array}$ \\
\hline
\end{tabular}

A from pig lungs with $P$. multocida isolation. Although this serotype has been described as a primary role in the induction of lesions in the respiratory tract (Paladino et al. 2017, Oliveira Filho et al. 2018), in this study we did not observe lesions suggestive of $P$. multocida highly pathogenic strain. The frequent isolation of $P$. multocida type A (43.3\%; 65/150) in our study is probably related to the correlation between Mycoplasma hyopneumoniae and $P$. multocida type A infections (Takeuti et al. 2013), as we found an average prevalence, in all lungs, of $79.3 \%$ of $M$. hyopneumoniae positive samples by qPCR, reaching $100 \%$ of the lungs from company $\mathrm{D}$. The pathogenic mechanisms of this correlation are suggested to be due to the L-fucose composition increased by $M$. hyopneumoniae and thereby enhancing the adherence of $P$. multocida type $\mathrm{A}$ to the bronchial and bronchiolar epithelial cells (Park et al. 2016). In our study, $42.7 \%$ of the samples which presented P. multocida type A isolation also showed histopathological lesions suggestive of $M$. hyopneumoniae and/or IAV infection, which demonstrates the importance of $P$. multocida type A as a secondary causative agent of pig pneumonia (Takeuti et al. 2013, Morés et al. 2015). In this study, P. multocida was not considered as the primary agent of pneumonia in any case, while another study detected a low proportion of cases in which the bacterium was identified as the primary agent (Morés et al. 2015). As no lungs (0/150) showed pleuritis, necro-hemorrhagic areas of consolidation or nodules of necrosis, microaerophilic incubation was not performed. If the microscopic evaluation had presented suggestive lesions of Actinobacillus pleuropneumoniae or Glaesserella parasuis (formerly Haemophilus parasuis), the PCR testing would be performed in order to detect these agents.

Mycoplasma hyopneumoniae is one of the most relevant bacteria in swine production (Pieters \& Maes 2019). It is the causative agent of Enzootic Pneumonia and has an important role in the PRDC, facilitating other bacteria or virus infections (Thacker et al. 1999, Park et al. 2016, Pieters \& Maes 2019). A total of $79.3 \%$ of the lungs were positive for M. hyopneumoniae by qPCR and four out of five companies presented a high

Table 3. An overall view of correspondence of lungs with histopathologic Mycoplasma hyopneumoniae (Mhyo) suspected lesions and $M$. hyopneumoniae qPCR results regarding the five companies enrolled in the study

\begin{tabular}{lccc}
\hline \multirow{2}{*}{ Histological aspect } & \multirow{2}{*}{ Companies } & \multicolumn{2}{c}{ Mhyo qPCR } \\
\cline { 3 - 4 } & & Positive & Negative \\
\hline Bronchointerstitial & $\mathrm{A}$ & $70 \%(21 / 30)$ & $10 \%(3 / 30)$ \\
pneumonia with & $\mathrm{B}$ & $80 \%(24 / 30)$ & $6.7 \%(2 / 30)$ \\
BALT hyperplasia & $\mathrm{C}$ & $13.3 \%(4 / 30)$ & $60 \%(18 / 30)$ \\
& $\mathrm{D}$ & $90 \%(27 / 30)$ & $0 \%(0 / 30)$ \\
& $\mathrm{E}$ & $83.3 \%(25 / 30)$ & $3.3 \%(1 / 30)$ \\
No evidence of BALT & Total & $67.3 \%(101 / 150)^{\mathrm{a}}$ & $16 \%(24 / 150)^{\mathrm{b}}$ \\
hyperplasia & $\mathrm{A}$ & $20 \%(6 / 30)$ & $0 \%(0 / 30)$ \\
& $\mathrm{B}$ & $13.3 \%(4 / 30)$ & $0 \%(0 / 30)$ \\
& $\mathrm{C}$ & $3.3 \%(1 / 30)$ & $23.3 \%(7 / 30)$ \\
& $\mathrm{D}$ & $10 \%(3 / 30)$ & $0 \%(0 / 30)$ \\
& $\mathrm{E}$ & $13.3 \%(4 / 30)$ & $0 \%(0 / 30)$ \\
& Total & $12 \%(18 / 150) \mathrm{a}$ & $4.7 \%(7 / 150) \mathrm{b}$
\end{tabular}

qPCR = quantitative polymerase chain reaction, BALT = bronchusassociated lymphoid tissue; Different letters within a row indicate a statistically significant difference $(P<0.05)$ based on chi-square analysis. 
proportion of lungs positive for $M$. hyopneumoniae by PCR. This data emphasizes the importance of this bacterium in Brazilian finishing pigs, as previously reported (Takeuti et al. 2013, Vicente et al. 2013, Morés et al. 2015), which could be related to the high density of pig farms in Brazilian pig production areas and the very high prevalence of positive farms for $M$. hyopneumoniae in the country. It is important to note that $P$. multocida type A isolation was significantly lower in samples from company $\mathrm{C}$ when compared to all other companies. This may be related to the lower number of positive lungs for $M$. hyopneumoniae by qPCR.

Regarding histopathological analysis, 83.3\% of samples presented BALT (bronchus-associated lymphoid tissue) hyperplasia, although not all of them were positive on qPCR for M. hyopneumoniae. The high concordance of $67.3 \%(101 / 150)$ between qPCR positivity and histologic lesions suggestive of $M$. hyopneumoniae was expected, once BALT hyperplasia is a characteristic finding of fully developed mycoplasma pneumonia (Blanchard et al. 1992, Caswell \& Williams 2016). However, in 16\% (24/150) of the samples there was a disagreement between the presence of BALT hyperplasia and the lack of M. hyopneumoniae qPCR detection which could be due to the fact that BALT hyperplasia is not a pathognomonic histopathologic lesion for M. hyopneumoniae, and can be seen in cases of pneumonic lesions caused by other agents as IAV (Laisse et al. 2018). In addition, a total of $12 \%(18 / 150)$ of the samples were $M$. hyopneumoniae positive by qPCR without presenting BALT hyperplasia. As M. hyopneumoniae has a very chronic and long-term infection in pigs (Pieters \& Maes 2019), the detection of these microorganism without histopathologic lesions could be associated with a recent or very mild infection with not enough time to cause microscopic lesions, such as BALT hyperplasia. Additionally, in this study, bronchointerstitial pneumonia was a very common finding and could be attributed both to M. hyopneumoniae and IAV (Schaefer et al. 2013, Caswell \& Williams 2016).

After the emergence of pandemic H1N1 Influenza A virus (IAV) in 2009, the IAV has been reported as an important agent of the PRDC in Brazilian swine production (Rajão et al. 2013, Rech et al. 2018). The presence of pigs showing clinical signs of IAV infection is frequently associated with the nursery phase, probably due to the decrease of the levels of maternal immunity and the increase of infection susceptibility (Van Reeth \& Vincent 2019). Ciacci-Zanella et al. (2015) found an average prevalence of antibodies against IAV in Brazilian pig herds of $78.1 \%$ in the nursery phase. However, in our work we found a high prevalence of IAV suggestive histopathological lesions (64.6\%) also in finishing pigs. All companies showed high frequency of positive samples, which ranged from $70 \%$ to $86.7 \%$, except for company $\mathrm{C}$, which presented the lowest result $(20 \%)$. As the IAV infection has a fast resolution, with convalescence around seven days after infection (Schaefer et al. 2013), and the histopathologic lesions resolution occurs within three weeks after infection (Janke 2000), the IAV lesions found in this work probably occurred during the finishing phase, which is not commonly reported. The gross lesions found in uncomplicated IAV infection are limited to the apical and cardiac lobes of the lung (Van Reeth \& Vincent 2019), the same pulmonary lobes affected by M. hyopneumoniae, which may result in misleading diagnosis when laboratory tests are note performed. The similarity of subacute or chronic histopathologic lesions of IAV with initial lesions of $M$. hyopneumoniae infection, especially in cases where the lymphocytic infiltrate forms a ring around the bronchioles (Janke 2014), may confuse the diagnostics between those microorganisms by histopathologic examination. Taking this fact into account, we submitted samples with IAV subacute and acute histopathological lesions to IHC and real-time RT-PCR for IAV and we observed a total of 35\% and $13 \%$ of positive results for IAV, respectively. Detection of IAV has been reported to be possible for no more than 11 days post infection (p.i.) by real-time RT-PCR (Lange et al. 2009) and 13 days p.i. by IHC (Weingartl et al. 2010). This difference could justify the higher detection by IHC than real time RT-PCR in our study. Another explanation could be related to the multifocal distribution of lesions or the condition of the samples (Vincent et al. 1997), since they were collected from different areas of the lungs. These findings emphasize the importance of laboratory diagnostic of pig pneumonia and the relevance of IAV infection in pigs also during the finishing phase, which should be considered in the differential diagnosis of pneumonic lesions in pigs. In addition, more studies regarding the infection dynamics of this virus in Brazilian pig herds, especially during the finishing phase should be performed.

Although other microorganisms have been reported to contribute to the Porcine Respiratory Disease Complex (PRDC), only IAV, $M$. hyopneumoniae and $P$. multocida type A were found in this work. The lack of additional histopathological lesions suggestive of other agents was the reason for no further tests. No evidences of PCV2 infection were observed in all lungs assessed in this study, which was expected since the virus usually affects younger pigs, and due to the good control of infection by commercial vaccines usage (Morés et al. 2015). In addition, PRRSv and PRCv are important virus in the world pig industry but they have never been reported in Brazil (Rech et al. 2018), so the absence of suggestive lesions for the agents was expected.

The presence of more than one infectious agent within all lungs from five companies was detected in $68 \%$ of the samples regarding histopathological, bacteriological and molecular findings. This data demonstrated the importance of coinfections in pig lungs at slaughter age, being $M$. hyopneumoniae, IAV and P. multocida type A the three most frequent microorganisms identified in our study. Although M. hyopneumoniae, P. multocida and Influenza A virus had already been describe as the most relevant aggravating of PRDC in Brazil within pigs from all ages (Rech et al. 2018), the high frequency of IAV in slaughtered pigs was an unexpected finding, as previous work have observed only a $2.8 \%$ frequency in fattening pigs (Morés et al. 2015). These findings have an important economic impact, since the economic losses due to coinfections between IAV and M. hyopneumoniae were estimated to be 16 times greater than single infections caused only by M. hyopneumoniae (Haden et al. 2012). Furthermore, our results suggest that those microorganisms should be taken into account in order to control pig pneumonia at the end of the finishing phase in Brazilian pig farms.

\section{CONCLUSION}

The data of this work highlight the coinfection roll of Mycoplasma hyopneumoniae, Influenza A virus (IAV) and Pasteurella multocida type A as the main agents of the Porcine 
Respiratory Disease Complex in pigs from Brazil. Moreover, we highlight the high frequency of lesions caused by IAV and the identification of the virus by real time RT-PCR in pigs at slaughter age, even though IAV is not typically associated with infections and clinical cases in pigs in this phase.

Acknowledgements.- This project was funded by "Conselho Nacional de Desenvolvimento Científico e Tecnológico” (CNPq), "Fundo de Desenvolvimento e Defesa Sanitária Animal" (FUNDESA) and Boehringer Ingelheim Animal Health. The authors acknowledge all participating students and veterinarians in sample collections.

Conflict of interest statement.- The authors declare that they have no competing interest.

\section{REFERENCES}

Allen T.C. 1992. Hematoxylin and eosin, p.53-58. In: Prophet E.B., Mills R., Arrington J.B. \& Sobin L.H. (Eds), Laboratory Methods in Histotechnology. American Registry of Pathology, Washington, D.C.

Blanchard B., Vena M.M., Cavalier A., Le Lannic J., Gouranton J. \& Kobisch M. 1992. Electron microscopic observation of the respiratory tract of SPF piglets inoculated with Mycoplasma hyopneumoniae. Vet. Microbiol. 30(4):329-341. <https://dx.doi.org/10.1016/0378-1135(92)90020-t> $<$ PMid:1533978>

Brewster V.R., Maiti H.C., Tucker A.W. \& Nevel A. 2017. Associations between EP-like lesions and pleuritis and post trimming carcass weights of finishing pigs in England. Livest. Sci. 201:1-4. <https://dx.doi.org/10.1016/j. livsci.2017.04.012>

Caswell J.L. \& Williams K.J. 2016. Respiratory system, p.526-527. In: Jubb K.P. (Ed.), Pathology of Domestic Animals. 6th ed. St Louis, Missouri.

Ciacci-Zanella J.R., Schaefer R., Gava D., Haach V., Cantão M.E. \& Coldebella A. 2015. Influenza A virus infection in Brazilian swine herds following the introduction of pandemic 2009 H1N1. Vet. Microbiol. 180(1/2):118-122. <https://dx.doi.org/10.1016/j.vetmic.2015.08.021><PMid:26345257>

Fablet C., Marois C., Dorenlor V., Eono F., Eveno E., Jolly J.P., Devendec L., Kobisch M., Madec F. \& Rose N. 2012. Bacterial pathogens associated with lung lesions in slaughter pigs from 125 herds. Res. Vet. Sci. 93(2):627-630. <https://dx.doi.org/10.1016/j.rvsc.2011.11.002><PMid:22133708>

Fraile L., Alegre A., López-Jiménez R., Nofrarías M. \& Segalés J. 2010. Risk factors associated with pleuritis and cranio-ventral pulmonary consolidation in slaughter-aged pigs. Vet. J. 184(3):326-333.<https://dx.doi.org/10.1016/j. tvjl.2009.03.029><PMid:19527939>

Haden C., Painter T., Fangman T. \& Holtkamp D. 2012. Assessing production parameters and economic impact of swine Influenza, PRRS and Mycoplasma hyopneumoniae on finishing pigs in a large production system. AASV Annu. Meet. 75-76.

Janke B.H. 2000. Diagnosis of swine influenza. Swine Heal. Prod. 8(2):79-84.

Janke B.H. 2014. Influenza A virus infections in swine: pathogenesis and diagnosis. Vet. Pathol. 51(2):410-426.<https://dx.doi.org/10.1177/0300985813513043> $<$ PMid:24363301>

Karabasil N., Cobanovic N., Vucicevic I., Stajkovic S., Becskei Z., Forgách P. \& Aleksic-Kovacevic S. 2017. Association of the severity of lung lesions with carcass and meat quality in slaughter pigs. Acta Vet. Hung. 65(3):354-365. <https://dx.doi.org/10.1556/004.2017.034><PMid:28956483>

Laisse C.J.M., Bianchi M.V., Pereira P.R., De Lorenzo C., Pavarini S.P. \& Driemeier D. 2018. Infecção pelo vírus Influenza A em suínos no sul de Moçambique. Pesq. Vet. Bras. 38(8):1484-1490. <https://dx.doi.org/10.1590/1678-5150-pvb-5291>

Lange E., Kalthoff D., Blohm U., Teifke J.P., Breithaupt A., Maresch C., Starick E., Fereidouni S., Hoffmann B., Mettenleiter T.C., Beer M. \& Vahlenkamp T.W. 2009. Pathogenesis and transmission of the novel swine-origin Influenza virus A/H1N1 after experimental infection of pigs. J. Gen. Virol. 90:2119-2123. <https://dx.doi.org/10.1099/vir.0.014480-0> <PMid:19592456>

Loving C.L., Brockmeier S.L., Vincent A.L., Palmer M.V., Sacco R.E. \& Nicholson T.L. 2010. Influenza virus coinfection with Bordetella bronchiseptica enhances bacterial colonization and host responses exacerbating pulmonary lesions. Microb. Pathog. 49(5):237-245. <https://dx.doi.org/10.1016/j. micpath.2010.06.004><PMid:20558274>

Madec F. \& Kobisch M. 1982. Bilan lésionnel des poumons de porcs charcutiers à l'abattoir. Journées Recherche Porcine, Paris, 14:405-412.

Markey B., Leonard F., Archambault M., Cullinane A. \& Maguire D. 2013. Clinical Veterinary Microbiology. 2nd ed. Mosby Elsevier Ltd., Dublin.

Morés M.A.Z., Oliveira Filho J.X., Rebelatto R., Klein C.S., Barcellos D.E.N., Coldebella A. \& Morés N. 2015. Aspectos patológicos e microbiológicos das doenças respiratórias em suínos de terminação no Brasil. Pesq. Vet. Bras. 35(8):725-733.<https://dx.doi.org/10.1590/S0100-736X2015000800004>

Oliveira Filho J.X., Morés M.A.Z., Rebellato R., Kich J.D., Cantão M.E., Klein C.S., Guedes R.M.C., Coldebella A., Barcellos D.E.N \& Morés N. 2018. Pathogenic variability among Pasteurella multocida type A isolates from Brazilian pig farms. BMC Vet. Res. 14(1):244. <https://dx.doi.org/10.1186/s12917018-1565-2><PMid:30134904>

Paladino E.S., Gabardo M.P., Lunardi P.N., Morés N. \& Guedes R.M.C. 2017. Anatomopathological pneumonic aspects associated with highly pathogenic Pasteurella multocida in finishing pigs. Pesq. Vet. Bras. 37(10):1091-1100. <https://dx.doi.org/10.1590/s0100-736x2017001000009>

Park C., Jeong J., Kang I., Choi K., Park S.J. \& Chae C. 2016. Increased fucosyl glycoconjugate by Mycoplasma hyopneumoniae enhances adherences of Pasteurella multocida type A in the ciliated epithelial cells of the respiratory tract. BMC Vet. Res. 12:1-6. <https://dx.doi.org/10.1186/s12917-016-0650-7> <PMid:26841756>

Pieters M. \& Maes D. 2019. Mycoplasmosis, p.863-883. In: Zimmerman J., Karriker L., Ramirez A., Schwartz K., Stevenson G. \& Zhang J. (Eds), Diseases of Swine. 11th ed. Wiley, Ames.

Pointon A.M., Byrt D. \& Heap P. 1985. Effect of enzootic pneumonia of pigs on growth performance. Aust. Vet. J. 62(1):13-18. <https://dx.doi. org/10.1111/j.1751-0813.1985.tb06032.x> <PMid:3924012>

R Core Team 2013. R: A Language and Environment for Statistical Computing. R Foundation for Statistical Computing, Vienna. Available at <http:// softlibre.unizar.es/manuales/aplicaciones/r/fullrefman.pdf> Accessed on Mar. 30, 2020.

Rajão D.S., Alves F., Puerto H.L.D., Braz G.F., Oliveira F.G., Ciacci-Zanella J.R., Schaefer R., Reis J.K.P., Guedes R.M.C., Lobato Z.I.P. \& Leite R.C. 2013. Serological evidence of swine Influenza in Brazil. Influenza Other Respir. Viruses 7(2):109-112. <https://dx.doi.org/10.1111/j.1750-2659.2012.00366.x> $<$ PMid:22487322>

Rech R.R., Gava D., Silva M.C., Fernandes L.T., Haach V., Ciacci-Zanella J.R. \& Schaefer R. 2018. Porcine respiratory disease complex after the introduction of H1N1/2009 Influenza virus in Brazil. Zoonoses Public Health 65(1):e155-e161. <https://dx.doi.org/10.1111/zph.12424> <PMid:29139241>

Schaefer R., Rech R.R., Silva M.C., Gava D. \& Ciacci-Zanella J.R. 2013. Orientações para o diagnóstico de influenza em suínos. Pesq. Vet. Bras. 33(1):61-73. <https://dx.doi.org/10.1590/S0100-736X2013000100012>

Silva A.F., Paganini F.J., Acosta J.C., Rocha P.H., Mistura H., Marcon E., Simon V.A., Casagrande H.A., Silva M.S. \& Floss J.M. 2002. Prevalence of respiratory diseases in swine at slaughterhouses in Brazil. Congr. Int. Pig Vet. Soc. 17:332.

Straw B.E., Shin S.J. \& Yeager A.E. 1990. Effect of pneumonia on growth rate and feed efficiency of minimal disease pigs exposed to Actinobacillus pleuropneumoniae and Mycoplasma hyopneumoniae. Prev. Vet. Med. 9(4):287-294. <https://dx.doi.org/10.1016/0167-5877(90)90074-R>

Takeuti K.L., Barcellos D.E.S.N., Andrade C.P., Almeida L.L. \& Pieters M. 2017. Infection dynamics and genetic variability of Mycoplasma hyopneumoniae 
in self-replacement gilts. Vet. Microbiol. 208:18-24. <https://dx.doi. org/10.1016/j.vetmic.2017.07.007> <PMid:28888635>

Takeuti K.L., Watanabe T.T.N., de Castro L.A., Driemeier D. \& de Barcellos D.E.S.N. 2013. Caracterização histopatológica e imuno-histoquímica da pneumonia causada pela co-infecção por Pasteurella multocida e Mycoplasma hyopneumoniae em suínos. Acta Sci. Vet. 41(1):1-6.

Thacker E.L., Halbur P.G., Ross R.F., Thanawongnuwech R. \& Thacker B.J. 1999. Mycoplasma hyopneumoniae potentiation of Porcine Reproductive and Respiratory Syndrome virus-induced pneumonia. J. Clin. Microbiol. 37(3):620-627. <https://dx.doi.org/10.1128/JCM.37.3.620-627.1999> <PMid:9986823>

Van Reeth K. \& Vincent A.L. 2019. Influenza viruses p.576-593. In: Zimmerman J., Karriker L., Ramirez A., Schwartz K., Stevenson G. \& Zhang, J. (Eds.), Diseases of Swine. 11th ed. Wiley, Ames.

Vicente A.F., Catto D., Allendorf S.D., Garcia K.C.O.D., Antunes J.M.A.P., Appolinario C.M., Peres M.G. \& Megid J. 2013. Soropositividade para Mycoplasma hyopneumoniae em suínos abatidos em frigoríficos da região central do estado de São Paulo. Arq. Bras. Med. Vet. Zootec. 65(6):1899-1903. <https://dx.doi.org/10.1590/S0102-09352013000600045>
Vincent L.L., Janke B.H., Paul P.S. \& Halbur P.G. 1997. A monoclonal-antibodybased immunohistochemical method for the detection of swine Influenza virus in formalin-fixed, paraffin-embedded tissues. J. Vet. Diagn. Invest. 9(2):191-195. <https://dx.doi.org/10.1177/104063879700900214> $<$ PMid:9211240>

Watanabe T.T.N., Almeida L.L., Wouters F., Wouters A.T.B., Zlotowski P. \& Driemeier D. 2012. Histopathological and immunohistochemical findings of swine with spontaneous Influenza infection in Brazil, 2009-2010. Pesq. Vet. Bras. 32(11):1148-1154.<https://dx.doi.org/10.1590/S0100736X2012001100013>

Weingartl H.M., Berhane Y., Hisanaga T., Neufeld J., Kehler H., Emburry-Hyatt C., Hooper-McGreevy K., Kasloff S., Dalman B., Bystrom J., Alexandersen S., Li Y. \& Pasick J. 2010. Genetic and pathobiologic characterization of pandemic H1N1 2009 Influenza viruses from a naturally infected swine herd. J.Virol. 84(5):2245-2256. <https://dx.doi.org/10.1128/JVI.02118-09> <PMid:20015998>

WHO 2009. CDC Protocol of Realtime RTPCR for Swine Influenza A(H1N1). World Health Organization, Geneva. Available at <http://www.who.int/csr/ resources/publications/swineflu/CDCrealtimeRTPCRprotocol_20090428.pdf> Accessed on Mar. 30, 2020. 